\title{
A Competency Approach as a Methodological Basis in the Formation of Performing Skills in Future Music Teachers and Musicians From China
}

\author{
Lu Tao \\ ORCID https://orcid.org/0000-0002-0008-5134 \\ Postgraduate student \\ Dragomanov National Pedagogical University (Ukraine, Kyiv)
}

\begin{abstract}
The article is devoted to the study of the content of the competence approach. The key concepts of competency approach: competence, competence, competence, as well as competence in the musical-performing field, competence of the music teacher, professional music competence, musical-performing competence of the future teacher of music are analyzed and presented. The relevance and expediency of the use of a competent approach in the formation of performing skills of future music teachers of China is substantiated. It is revealed that the application of a competent approach in the formation of the performing arts of future music teachers of China allows: to establish and develop interrelationships between personality, education and profession; to select the content of vocational education, respectively, to the needs of the developing person, and to the actual professional requirements due to the peculiarities of modern music and pedagogical practice; direct the formation of executive competence for the perfect possession of the instrument in order to ensure the maximum artistic influence on the development of the child's personality and the implementation of many other pedagogical tasks.
\end{abstract}

Key words: future teacher-musician, China, competency approach, competence, performing skills.

Актуальність дослідження. Процеси глобалізації та інтеграції є найхарактернішою особливістю розвитку сучасного світу. Ці процеси притаманні усім без винятку сферам людського життя. В освіті вони виявляються у розробці та впровадженні нових методологічних підходів: таких, що відповідають мінливим вимогам сьогодення та орієнтовані не лише на становлення особистості, а й на формування конкретних уніфікованих здатностей до здійснення певної професійної діяльності, що забезпечують затребуваність фахівця на ринку праці у будь-якій країні. Підходом, що дозволяє ефективно вирішувати вищевикладені завдання на всіх рівнях освіти та у всіх її галузях (зокрема, мистецькій), сформувати виконавську майстерність майбутніх педагогів-музикантів Китаю в педагогічних університетах України таким чином, що вони зможуть успішно застосовувати іiі у розв'язанні фахових завдань як у себе на батьківщині, так і у всьому світі - $є$ компетентнісний. Це і буде метою даної статті.

Виклад основного матеріалу. Компетентнісний підхід є методологічною 
основою сучасної освіти та одним із напрямів педагогічних досліджень вищої школи. Завдяки компетентнісному підходу, стверджує Л. Теряєва, людина формується як особистість, фахівець і громадянин [14].

Проблеми реалізації компетентнісного підходу на різних щаблях освітнього процесу вивчали Л. Антонюк, Ю. Багно, Є. Зеєр, О. Кулик, Л. Овсієнко, Дж.Равен, Г. Селевко, Ю. Татур, Л. Теряєва, А. Хуторський, О. Шахматова та ін. Питання функціонування компетентнісного підходу в галузі мистецької освіти, зокрема, у підготовці майбутніх учителів музики досліджували С. Булгакова, С. Грозан, А. Казурова, Ю. Калиніна, С. Світайло, О. Щолокова, В. Яковлєв та ін.

Компетентнісний підхід (КП) в освіті розглядається науковцями як сукупність загальних принципів визначення цілей освіти, вибору змісту освіти, організації освітнього процесу, оцінки результатів освіти. КП передбачає пріоритетну орієнтацію на цілі освіти: якість освіти, здатність до навчання, самовизначення, самоактуалізацію, самореалізацію, соціалізацію і розвиток індивідуальності учня. Метою реалізації КП в професійній освіті є формування компетентного фахівця, що володіє всіма необхідними компетентностями у професійній діяльності.

Перехід до компетентнісного підходу означає переорієнтацію 3 процесу на результат освіти в діяльнісному вимірюванні, у зміщенні акценту з накопичування нормативно визначених знань, умінь і навичок на формування й розвиток в учнів здатності практично діяти, застосовувати досвід успішних дій у конкретних ситуаціях, на організацію освітнього процесу на основі тверезого урахування затребуваності навчальних досягнень випускника школи в суспільстві, забезпечення його спроможності відповідати реальним запитам швидко змінюваного ринку й мати сформований потенціал для швидкої безболісної адаптації як у майбутній професії, так і в соціальній структурі [4].

С. Булгакова відзначає, що застосування КП у підготовці майбутніх працівників системи музичного виховання і освіти диктує свої особливі вимоги як до структури, рівня й змісту навчального процесу, так і до особистості вчителя музики [2]. Зокрема, як стверджує С. Грозан, компетентнісний підхід в мистецькій освіті передбачає формування у студентів вищих навчальних закладів музичних компетенцій, тобто необхідного комплексу знань, навичок, відносин та досвіду, що допоможе реалізувати 
професійну підготовку майбутніх учителів, сформувати у них готовність до самореалізації у музично-освітній діяльності [3]. С. Світайло зазначає, що сучасна компетентнісна концепція спрямована на удосконалення підготовки майбутніх педагогів-музикантів шляхом формування у них фахової компетентності як складової професіоналізму, яка охоплює особистісні характеристики, теоретичні знання, практичні здатності у сфері професійної діяльності [11].

Методологічною підставою реалізації компетентнісного підходу в професійній освіті виступають принципи: варіативності освіти; спрямованості освіти на розвиток і саморозвиток особистості; поєднання автономності 3 колективними та груповими формами освіти; нестійкої динамічної рівноваги освітнього процесу як джерела розвитку взаємозв'язків особистості, освіти та професії; співрозвитку особистості, освіти та діяльності [6].

Отже, «компетентнісний підхід» розглядають як методологічну основу оновлення змісту, цілей, якості вищої освіти [14] та розуміють як спрямованість освітнього процесу на формування й розвиток ключових (базових, основних, надпредметних) і предметних компетентностей особистості $[4 ; 12 ; 13 ; 15 ; 17]$.

Слід відзначити, що на сьогоднішній день не існує усталених визначень ключових понять компетентнісного підходу: вони все ще залишаються предметом обговорень та дискусій. Так, у сучасних психолого-педагогічних дослідженнях поняття «компетенція» тлумачать як сукупність професійних знань, умінь, способів виконання професійної діяльності (Є. Зеєр, О. Шахматова [5]); «компетентність» - як специфічну здатність, що необхідна для ефективного виконання конкретної дії у конкретній предметній галузі та включає вузькоспеціальні знання, особливого роду предметні навички, способи мислення, а також розуміння відповідальності за свої дії (Дж.Равен [10]). Поняття «компетенщія у музично-виконавській сфері» розуміють як здатність до успішного вирішення професійних завдань у виконавській, науковій, творчій, педагогічній галузях діяльності на основі набутих знань, умінь і навичок [7]. «Професійну компетентність педагога» трактують як єдність теоретичної і практичної підготовленості до здійснення педагогічної діяльності, що характеризує його професіоналізм [1].

Дослідники професійної компетентності учителя музики відзначають, що вона 
має свою специфіку, визначається метою і змістом музично-освітньої діяльності в школі. Компетентність учителя музики розуміється як: особистісна якість, яка виявляється суто у професійній діяльності (С. Булгакова [2]); особистісне утворення, складне, динамічне за своєю структурою, яке можна модифікувати відповідно до змісту і рівня освіти (С. Світайло [11]); якість реалізації на практиці результату формування в суб'єктів навчання фахових музичних компетенцій, визначення яких $\epsilon$ важливою методологічною позицією для аналізу цього феномену i керування процесом його формування (С. Грозан [3]).

С. Булгакова стверджує, що у новій освітній парадигмі навчальні дисципліни немов би «випливають» із компетенцій. По суті, компетенції є професіограмою, в якій відображена повна кваліфікаційна характеристика вчителя музики з позицій вимог, що пред'являються не тільки до його знань, умінь, володіння, а й до його особистості, здібностей, психофізіологічних можливостей [2].

Професійну компетентність учителя музики поряд 3 багатьма іншими компетенціями складають фахові музичні компетенції. Вони зумовлюють успішну самореалізацію майбутнього вчителя у музично-освітній діяльності та здійснення музично-педагогічного впливу. С. Грозан розуміє фахові музичні компетенції як сукупність базових музичних знань, сформованих умінь і навичок елементарного музикування (виконавства), оцінної діяльності та досвіду творчої музичної діяльності [3].

На думку В. Яковлєва, яку поділяємо і ми, ядром професійної компетентності вчителя музики загальноосвітньої школи $є$ його музично-виконавська компетентність. Науковець визначає музично-виконавську компетентність майбутнього вчителя музики як інтегративне утворення особистості, що має системну організацію, складну багаторівневу структуру і виступає як сукупність, взаємодія особистісного, когнітивнодіяльнісного і рефлексивного компонентів, ступінь сформованості яких дозволяє вчителеві музики ефективно здійснювати музично-виконавську діяльність. В. Яковлєв наголошує, що музично-виконавська компетентність дає можливість майбутньому вчителю музики усвідомити себе суб'єктом музично-виконавської діяльності та дозволяє удосконалюватися у професійному й особистісному плані [16].

Висновки. Отже, питанням компетентнісного підходу присвячені праці 
багатьох вчених. КП вважається науковцями провідним методологічним орієнтиром у модернізації сучасної освіти, суть якого полягає у формуванні та розвитку в учнів компетентностей, що забезпечують успішну професійну діяльність. Компетентності педагога-музиканта складаються з компетенцій, які, з одного боку, є наперед заданими освітніми вимогами, в яких відображена кваліфікаційна характеристика учителя музики, а з іншого - сукупністю набутих, розвинутих, сформованих та інтегрованих в процесі музичного навчання здібностей, знань, умінь, навичок та якостей, що дозволяють здійснювати успішну музично-педагогічну діяльність.

Професійна компетентність учителя музики визначається метою та змістом музично-освітньої діяльності у школі. Вона є інтегральною особистісною якістю, що утворюється у результаті набуття музичного, педагогічного й життєвого досвіду та забезпечує професійну самореалізацію педагога-музиканта на відповідному рівні. Музично-виконавська компетентність розглядається вченими як ядро професійної компетентності учителя музики загальноосвітньої школи; як інтегративне утворення особистості, що має системну організацію та складну багаторівневу структуру. Виконавська майстерність передбачає високий рівень виконавської компетентності. Відтак, застосування компетентнісного підходу у формуванні виконавської майстерності майбутніх педагогів-музикантів Китаю дозволяє: встановити та розвинути взаємозв'язки особистості, освіти та професії; здійснити відбір змісту професійної освіти відповідно як до потреб особистості, що розвивається, так і до актуальних професійних вимог, зумовлених особливостями сучасної музично-педагогічної практики; спрямувати формування виконавської компетентності на досконале володіння інструментом задля забезпечення максимального художнього впливу на становлення особистості дитини та реалізації багатьох інших педагогічних завдань.

\section{References}

1. Bagno Yu.N., Sergeychuk E.N. Kompetentnostnyiy podhod v sisteme prakticheskoy podgotovki buduschih uchiteley [Competence approach in the system of practical training of future teachers]. Nauchno-metodicheskiy elektronnyiy zhurnal «Kontsept». 2014. No 09 (sentyabr). P. 141-145. ART 14255. 0,4 p. 1. URL: http://e-koncept.ru/2014/14255.htm.

2. Bulgakova S.N. Tendentsii vyisshego professionalnogo muzyikalnopedagogicheskogo obrazovaniya: kompetentnostnyiy podhod [Tendencies of higher professional musical and pedagogical education: competence approach]. Vestnik Chelyabinskoy gos. akademii kulturyi i iskusstv. 2009. No 3 (19). P. 120-123. 
3. Grozan S. Kompetentnisniy pidhid yak skladova chastina pidgotovki maybutnogo vchitelya muziki do profesiynoyi samorealizatsiyi [Competency approach as an integral part of preparing the future teacher of music for professional self-realization]. Naukovi zapiski Kirovogradskogo derzh. ped. universitetu imeni V.Vinnichenka. Seriya: Pedagogichni nauky. 2014. Vol. 132. P. 282-285.

4. Zagalni ponyattya pro kompetentnisniy (diyalnisniy) pidhid $v$ osviti. NaukovometodichnI zasadi vprovadzhennya derzhavnogo standartu pochatkovoyi zagalnoyi osviti [General concepts of competency (activity) approach in education. Scientific and methodological principles of implementation of the state standard of elementary general education] // Proektuvannya ta provedennya uroku $\mathrm{v}$ pochatkovih klasah na zasadah kompetentnisnogo (diyalnisnogo) pidhodu: navchalne vidannya / B-ka zhurn. «Pochatkove navchannya ta vihovannya» ; uporyad. Drozhzhina T.V., Gezey O.M. H.: Vid. gruppa «Osnova», 2014. Vol. 8 (128). 127, [1] p.

5. Zeer E.F., Shahmatova O.N. Lichnostno orientirovannyie tehnologii professionalnogo razvitiya spetsialista: nauch.-metod. posobie [Personally oriented technologies of professional development of a specialist: scientific-method. allowance]. Ekaterinburg: Izd-vo UGPPU, 1999. 245 p.

6. Ibragimova L.A., Petrova G.A., Trofimenko M.P. Kompetentnostnyiy podhod metodologicheskaya osnova sovremennogo obrazovaniya [Competence approach - the methodological basis of modern education]. Vestnik Nizhnevartovskogo gos. un-ta. 2010. No 1. P. 57-66.

7. Kazurova A.S. Problemyi gosudarstvennogo obrazovatelnogo standarta vyisshego professionalnogo muzyikalnogo obrazovaniya: opyit i perspektivyi [Problems of the State Educational Standard of Higher Professional Music Education: Experience and Prospects]. Moskva: Issledovatelskiy tsentr problem kachestva podgotovki spetsialistov, 2005. 93 p.

8. Pet'ko L.V. Vyhovnyj $i$ profesijnyj aspekty muzychno-pedagogichnoi' sprjamovanosti navchannja inozemnoi' movy studentiv VNZ u systemi muzychnopedagogichnoi' osvity [Educational and professional aspects of music-pedagogical orientation of foreign language teaching for students in the system of music-pedagogical training] / Muzyka ta osvita : naukovo-metod.zhurnal / zasn. MON Ukrai'ny, NAPN Ukrai'ny, Kyi'vs'ka dytjacha akademija mystectv ; gol.red. L.M.Masol. Kyi'v : Pedagogichna dumka, 2013. № 3. C. 14-18.

9. Pet'ko L.V. Robota nad pisneju v kursi anglijs'koi' movy jak odyn iz zasobiv profesijnoi' pidgotovky studentiv gumanitarnyh special'nostej VNZ [The song in English course as a means of training humanities majors university students']. Inozemni movy. 2011. No 1. P. 44-48.

10. Raven Dzh. Pedagogicheskoe testirovanie: problemyi, zabluzhdeniya, perspektivyi: per. s angl. [Pedagogical testing: problems, misconceptions, perspectives]. Moskva: Kogito-Tsentr, 1999. 144 p.

11. Svitaylo S.V. Kompetentnisna pidgotovka vikladacha muzichnogo mistetstva [Competent training of the teacher of musical art] // Profesiyna mistetska osvita i hudozhnya kultura: vyklyki XXI stolittya : zb. mat. Mizhn. nauk.-prakt. konf. (Kiyiv, 16-17.10.2014). Kyiv: Kiyivskiy un-t im. B.Grinchenka, 2014. P. 670-675. 
12. Ternopilska V.I. Struktura profesiinoi kompetentnosti maibutnoho fakhivtsia [The structure of professional competence of a future specialist]. Naukovyi visnyk Melitopolskoho derzh. pedahohichnoho universytetu. Seriia: Pedahohika. 2012. Vol. 9. P. 208-213.

13. Ternopilska V.I. Modeliuvannia samoosvitnoi kompetentnosti maibutnikh fakhivtsiv [Modeling of self-education competence of future specialists]. Pedahohichna osvita: teoriia i praktyka. Psykholohiia. Pedahohika. 2016. Vol. 25. P. 6-22.

14. Teryaeva L.A. Formuvannya metodichnoyi kompetentnosti maybutnIh vchiteliv muziki: kategorialniy analiz problemy [Formation of methodical competence of future music teachers: categorical analysis of the problem] / Profesiyna mistetska osvita i hudozhnya kultura: vyklyki XXI stolittya : zb. mat. Mizhn. nauk.-prakt. konf. (Kiyiv, 16-17.10.2014). Kyiv: Kiyivskiy un-t im. B.Grinchenka, 2014. P. 675-682.

15. Shcholokova O.P. Novitni pidkhody ta tekhnolohii u profesiinii pidhotovtsi vchytelia mystetskykh dystsyplin [New approaches and technologies in professional art teachers training] // Innovative processes in education: Collective monograph. - AMEET Sp. z o.o., Lodz, Poland, 2017. P. 238-246.

16. Yakovlev V.S. Teoreticheskaya model formirovaniya muzyikalno-ispolnitelskoy kompetentnosti buduschogo uchitelya muzyiki [Theoretical model of the formation of musical and performing competence of the future music teacher]. Uchenyie zapiski. Elektronnyiy nauchnyiy zhurnal Kurskogo gosudarstvennogo universiteta. 2010. No 2 (14). P. 210-216.

17. Pet'ko Lyudmila. Preparing higher school graduates in foreshortening of leader competencies for 2020. Topical questions of contemporary science: Collection of scientific articles. Aspekt Publishing of Budget Printing Center, Taunton, MA 02780, United States of America, 2017. P. 467-472.

Translation of the Title, Abstract and References to the Author's Language

\section{УДК 278.011.3-051-047.22:78}

Лу Тао. Компетентнісний підхід як методологічна основа у формуванні виконавської майстерності майбутніх педагогів-музикантів Китаю.

Статтю присвячено вивченню змістовної сутності компетентнісного підходу. Проаналізовано та представлено розуміння науковцями ключових понять КП: компетенція, компетенції, компетентність. З'ясовано, що застосування компетентнісного підходу у формуванні виконавської майстерності майбутніх педагогів-музикантів Китаю дозволяє: встановити та розвинути взаємозв'язки особистості, освіти та професії; здійснити відбір змісту професійної освіти відповідно як до потреб особистості, що розвивається, так і до актуальних професійних вимог, зумовлених особливостями сучасної музично-педагогічної практики; спрямувати формування виконавської компетентності на досконале володіння інструментом задля забезпечення максимального художнього впливу на становлення особистості дитини та реалізації багатьох інших педагогічних завдань.

Ключові слова: компетентнісний підхід, компетенція, компетенції, компетентність, виконавська майстерність, майбутні педагоги-музиканти Китаю. 


\section{Лу Тао. Компетентностный подход как методологическая основа в формировании исполнительского мастерства будущих педагогов-музыкантов}

Китая.

Статья посвящена изучению содержательной сущности компетентностного подхода. Проанализировано и представлено понимание учеными ключевых понятий компетентностного подхода: компетенция, компетенции, компетентность. Установлено, что применение компетентностного подхода в формировании исполнительского мастерства будущих педагогов-музыкантов Китая позволяет: установить и развить взаимосвязи личности, образования и профессии; осуществить отбор содержания профессионального образования в соответствии как с потребностями развивающейся личности, так и с актуальными профессиональными требованиями, обусловленными особенностями современной музыкально-педагогической практики; направить формирование исполнительской компетентности на совершенное владение инструментом для обеспечения максимального художественного влияния на становление личности ребенка и реализации многих других педагогических задач.

Ключевье слова: компетентностный подход, компетенция, компетенции, компетентность, исполнительское мастерство, будущие педагоги-музыканты Китая.

\section{Література}

1. Багно Ю.Н., Сергейчук Е.Н. Компетентностный подход в системе практической подготовки будущих учителей. Научно-метод. электронный журнал «Концепт». 2014. № 09 (сентябрь). С. 141-145. ART 14255. 0,4 п. л. URL: http://ekoncept.ru/2014/14255.htm.

2. Булгакова С.Н. Тенденции высшего профессионального музыкальнопедагогического образования: компетентностный подход. Вестник Челябинской государственной академии культуры и искусств. 2009. №3 (19). С. 120-123.

3. Грозан С. Компетентнісний підхід як складова частина підготовки майбутнього вчителя музики до професійної самореалізації. Наукові записки Кіровоградського державного педагогічного університету імені В.Винниченка. Серія: Педагогічні науки. 2014. Вип. 132. С. 282-285.

4. Загальні поняття про компетентнісний (діяльнісний) підхід в освіті. Науковометодичні засади впровадження державного стандарту початкової загальної освіти // Проектування та проведення уроку в початкових класах на засадах компетентнісного (діяльнісного) підходу: навч. видання / Б-ка журн. «Початкове навчання та виховання» / упоряд. Дрожжина Т.В., Гезей О.М. Харків: Вид. группа «Основа», 2014. Вип. 8 (128). $127,[1] \mathrm{c}$.

5. Зеер Э.Ф., Шахматова О.Н. Личностно ориентированные технологии профессионального развития специалиста: науч.-метод. пособие. Екатеринбург: Изд-во УГППУ, 1999. 245 с.

6. Ибрагимова Л.А., Петрова Г.А., Трофименко М.П. Компетентностный подход методологическая основа современного образования. Вестник Нижневартовского государственного ун-та. 2010. № 1. С. 57-66.

7. Казурова А.С. Проблемы государственного образовательного стандарта 
высшего профессионального музыкального образования: опыт и перспективы. Москва: Исследовательский центр проблем качества подготовки специалистов, 2005. 93 с.

8. Петько Л.В. Виховний i професійний аспекти музично-педагогічної спрямованості навчання іноземної мови студентів ВНЗ у системі музично-педагогічної освіти. Музика та освіта : науково-метод.журнал / засн. МОН України, НАПН України, Київська дитяча академія мистецтв ; гол.ред. Л.М.Масол. Київ : Педагогічна думка, 2013. № 3. С. 14-18.

9. Петько Л.В. Робота над піснею в курсі англійської мови як один із засобів професійної підготовки студентів гуманітарних спеціальностей ВНЗ. Іноземні мови : наук.-метод. журн. / засн. Київський лінгвістичний ун-т і вид-во «Ленвіт» ; гол. ред. С.Ю.Ніколаєва. К. : Вид-во «Ленвіт», 2011. № 1 С. 44-48.

10. Равен Дж. Педагогическое тестирование: проблемы, заблуждения, перспективы: пер. с англ. Москва: Когито-Центр, 1999. 144 с.

11. Світайло С.В. Компетентнісна підготовка викладача музичного мистецтва // Професійна мистецька освіта і художня культура: виклики ХХІ століття: мат. міжн. наук.-практ. конф. (м. Київ, 16-17.10.2014р.). Київ: Київський ун-т ім. Б.Грінченка, 2014. C. 670-675.

12. Тернопільська B.I. Структура професійної компетентності майбутнього фахівця. Науковий вісник Мелітопольського держ. педагогічного університету. Серія: Педагогіка. 2012. Вип. 9. С. 208-213.

13. Тернопільська В.І. Моделювання самоосвітньої компетентності майбутніх фахівців. Педагогічна освіта: теорія і практика. Психологія. Педагогіка. 2016. Вип. 25. C. 6-22.

14. Теряєва Л.А. Формування методичної компетентності майбутніх вчителів музики: категоріальний аналіз проблеми // Професійна мистецька освіта і художня культура: виклики XXI століття: мат. міжн. наук.-практ. конф. (м. Київ, 16-17.10.2014р.). Київ: Київський ун-т ім. Б.Грінченка, 2014. С. 675-682.

15. Щолокова О.П. Новітні підходи та технології у професійній підготовці вчителя мистецьких дисциплін / О.П.Щолокова // Innovative processes in education: Collective monograph. - AMEET Sp. z o.o., Lodz, Poland, 2017. - P. 238-246.

16. Яковлев В.С. Теоретическая модель формирования музыкальноисполнительской компетентности будущого учителя музыки // Ученые записки. Электронный научн. журнал Курского гос. Ун-та. 2010. №2 (14). С. 210-216.

17. Pet'ko Lyudmila. Preparing higher school graduates in foreshortening of leader competencies for 2020. Topical questions of contemporary science: Collection of scientific articles. Aspekt Publishing of Budget Printing Center, Taunton, MA 02780, United States of America, 2017. P. 467-472. 